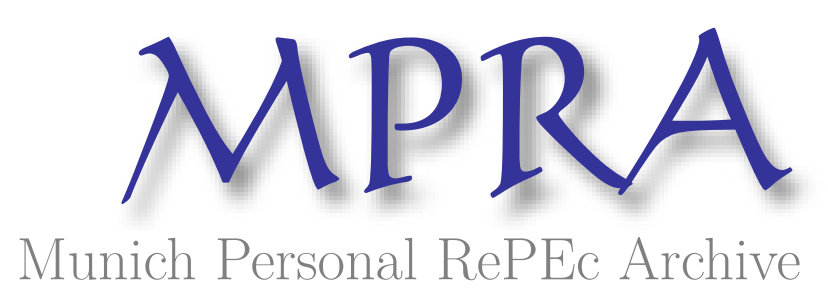

\title{
An Economic Theory of Islamic Finance Regulation
}

\author{
Al-Jarhi, Mabid \\ INCEIF, 2016
}

1 November 2015

Online at https://mpra.ub.uni-muenchen.de/72689/

MPRA Paper No. 72689, posted 25 Jul 2016 20:26 UTC 


\title{
AN ECONOMIC THEORY OF ISLAMIC FINANCE REGULATION
}

\author{
MABID ALI M. M. AL-JARHI
}




\section{CONTENTS}

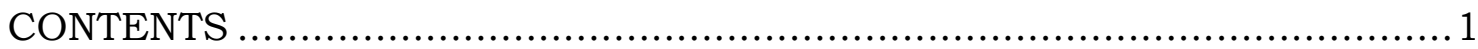

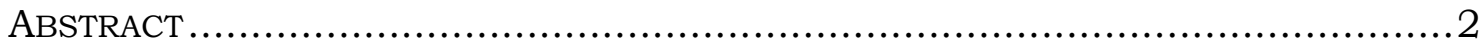

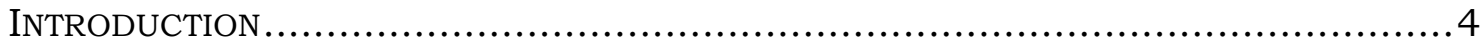

SECTION II: MARKET IMPERFECTIONS AND REGULATION ............................... 6

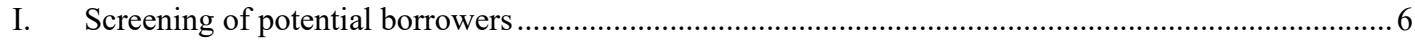

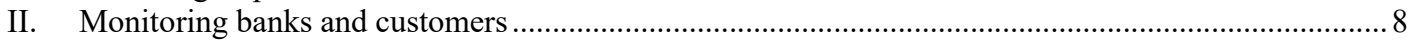

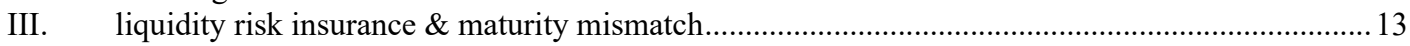

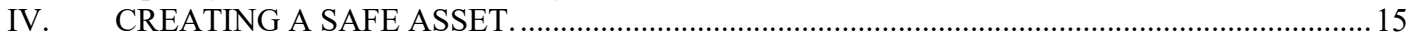

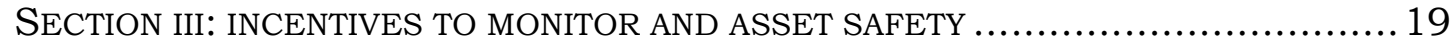

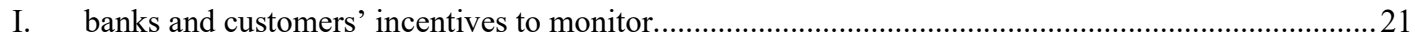

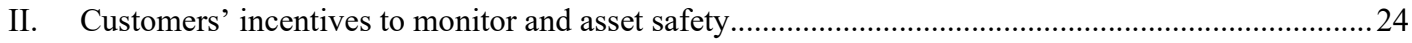

SECTION IV: MARKET FAILURES AND REGULATION ................................. 25

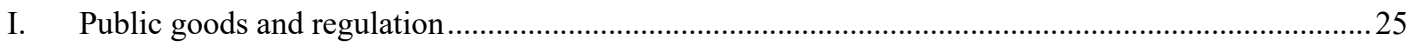

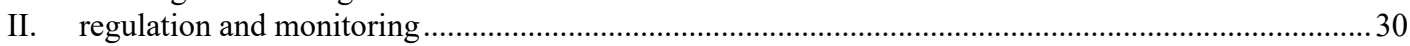

SECTION V: RELATED ISSUES OF MONETARY POLICY .................................. 34

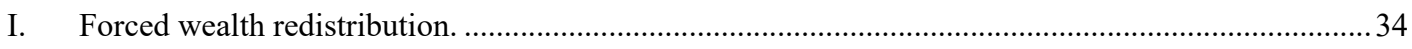

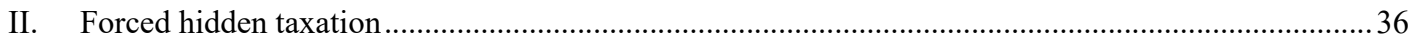

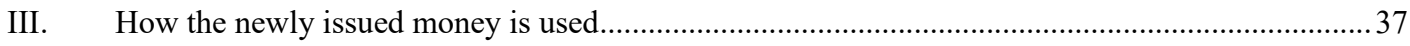

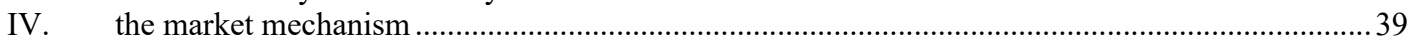

SECTION VI: AGGREGATE LIQUIDITY ........................................... 41

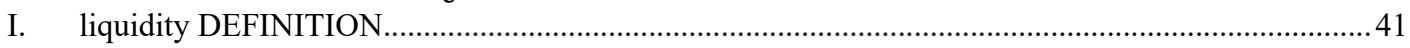

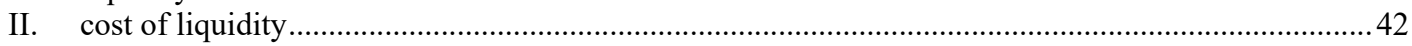

III. Derivative deposits and derivative investment accounts in Islamic banking .....................................43

IV. The effects of money creation by Islamic banks on prices.............................................................. 44

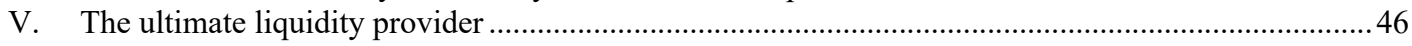

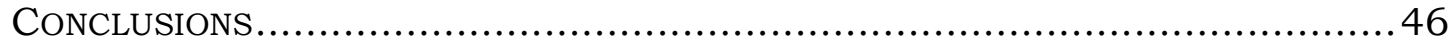

APPENDIX I: DEBT PREDICTABILITY, AN ILLUSTRATION .............................. 51

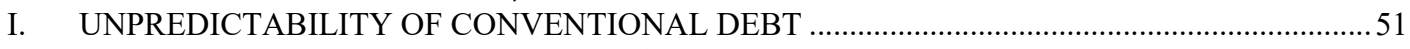

II. PREDICTABILITY OF DEBT UNDER Islamic FINANCE.........................................................52

APPENDIX II: DEFINITIONS OF ISLAMIC FINANCE AND INVESTMENT CONTRACTS ..........53

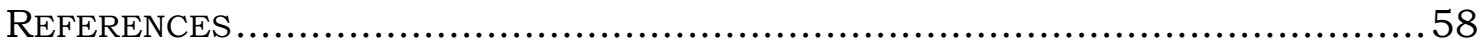




\section{ABSTRACT ${ }^{1}$}

We argue that regulation can improve the performance of conventional banks up to a limit, but cannot eliminate the deficiencies resulting from the use of the conventional loan contract.

Islamic finance requires complicated and costly procedures compared to conventional finance. Yet, it has significant macroeconomic benefits, which cannot be internalized by individual banks. Therefore, Islamic bankers tend to mimic conventional finance in order to cut costs and maximize short-term profits. Regulation can modify bankers' incentives in order to capture the benefits of Islamic finance.

Based on Al-Jarhi's macroeconomic model (1983), we construct an economic theory of Islamic banking regulation. Results point out to the potential of designing regulations that discourage mimicking conventional finance in order to benefit from the Islamic finance advantages.

Key words: Al-Jarhi's model, Islamic banking, Islamic finance, monetary economics, financial economics, banking, banking regulation, banking supervision, Islamic

\footnotetext{
${ }^{1}$ An earlier version was published in the Journal of Islamic Banking and Finance. This version includes significant changes. The author is currently a professor of economics and finance at the International Center for Education in Islamic Finance (INCEIF), Kuala Lumpur. The author is indebted to his MA students in the class of Legal and Supervisory Issues in Islamic Finance (Fall 2013/14), Hamad Bin Khalifa University, for transcribing some of the lecture notes related to the topic, and to his colleagues in INCEIF for helpful comments. Opinions expressed herein are the author's and do not necessarily represent those of INCEIF.

Readers unfamiliar with Islamic finance are well advised to start with reading the three appendices provided at the end of the paper.
} 
economics, financial economics, finance, financial intermediaries. 


\section{INTRODUCTION}

The economic theory of bank regulation can be considered as a part of the whole theory of regulation. The latter theory can take a normative approach, where regulation is justified by market failure or a positive approach where regulation is a result of the interaction between government bodies, banking and financial institutions as well as the active parties in the political process (Hebbink and Prast, 1998). Arguments of this approach are usually presented under the title of government failure. This paper attempts to complete the economic theory of bank regulation by covering the missing part related to Islamic finance.

Since Islamic finance has special characteristics that influence the extent of information asymmetry and introduces new questions related to monitoring, we expect the regulation theory related to conventional finance to be influenced. Some modifications would have to be ultimately introduced. While we focus on regulating Islamic banks, we try to point out some of the modifications required on the conventional banking side.

The economic theory of bank regulation attempts to explain why banks should be regulated and how. The theory provides two alternative justifications for bank regulation: government failures and market failures. While both types of failure seem to have some role, some economists, e. g., Heremans (2000) believe that market failures are becoming the dominant rationale for banking regulation ${ }^{2}$. Conventional finance, being based on the classical loan contract exposes financial intermediaries to information asymmetry. In addition, the banking industry

2 One way to explain this is to look into the increasing role of pressure groups in Western democracies, which is not sufficiently counterbalanced by the effectiveness of government branches. 
gravitates towards large-size banks. This has started the controversy whether regulations should focus on protecting such banks from failure or protecting finance users from insolvency or bankruptcy.

Islamic finance introduces a different twist to the story of regulation. It is not supposed to use the classical loan contract. Instead, there are sixteen financing contracts available some of which would be subject to information asymmetry and others would not. An Islamic financial intermediary would mix and match such contracts in order to structure the financing it provides to customers.

In addition, Islamic finance seem to provide macroeconomic benefits to the economy ${ }^{3}$. Since such benefits cannot be internalized, and since Islamic finance requires costlier and more roundabout methods to mix and match financing contracts, Islamic bankers find it more profitable to mimic conventional finance. Regulating Islamic banks must therefore be directed to establishing proper incentives to follow the true Islamic finance paradigm in order to benefit from its significant externalities. This is the core objective of our theory. In addition, such regulation must provide sufficient safeguards against information asymmetry and the exposure of Islamic banks to its resulting risking

The paper is organized in six parts. The first section starts by explaining the nature of an Islamic bank and whether they, like their conventional counterparts, emerged endogenously. The paper then explains why Islamic banks find it beneficial to mimic conventional banks. The second section discusses market imperfections in relation to Islamic finance, including screening, monitoring and liquidity risk. The third section discusses the incentives to monitor as related to asset safety. The forth section

\footnotetext{
${ }^{3}$ See Appendix II.
} 
discusses the relationship between market failures and regulation. Section five discusses some related issues of monetary policy. Issues of aggregate liquidity related to the proposed set of regulations are discussed in the last section. Finally, the paper summarizes its conclusions.

\section{SECTION II: MARKET IMPERFECTIONS AND REGULATION}

Four alternative theories have developed to explain why banks exist in response to financial market imperfections (Freixas and Santomero, 2002). Let us consider the implications of each for Islamic banking.

\section{SCREENING OF POTENTIAL BORROWERS}

Conventional banks screen potential clients ex ante on behalf of depositors), either because they are better at screening (Grossman and Stiglitz, 1980), or they do it on behalf of a large number of interested parties (Campbell and Kracaw, 1980). In both cases, banks enjoy economies of scale in monitoring (Ramakrishnan and Thakor, 1983).

However, the presence of economies of scale does not automatically lead to conventional banks actually monitoring their customers. Since monitoring is costly, conventional banks try to avoid it by requiring borrowers to provide collateral and guarantees. This happens to be the general trend in conventional banking. Banks prefer to take risk on collateral rather than sharing in the business risk of their customers.

In addition, monitoring would be generally restricted to large-volume transactions, where structured finance can be used. When a conventional bank finances a huge industrial or construction operation, it may find it economical to attach to it a system of monitoring. 
However, the majority of lending activities would not take such huge amounts of finance. In addition, borrowers with large financial requirements often find it to their advantage to resort to issuing bonds in financial markets in order to avoid monitoring, whose costs would be included in higher borrowing rates. That may explain the growth in issuing corporate bonds.

In Islamic finance, there is a need as well as an incentive for Islamic banks to screen finance users.

In financing consumption, consumers "compete" for the commodities by expressing their willingness to purchase each at a price or a markup over cost that is commensurate with their marginal value in use as well as their time preference related to each commodity ${ }^{4}$. Competition would result in an equilibrium that equates the price of each with its marginal value in use. In addition, commodities are financed through their sale against future payment or their future delivery against spot payment. Screening would therefore depend on the bidding by each customer in addition to the ability of each commodity financed to serve as collateral.

The issue of how much finance to allocate to each commodity is resolved through a process that invokes its value in use as well as the commodity time preference. Both Islamic and conventional finance benefit from the existence of economies of scale in screening consumers seeking finance. Islamic banks would also have a comparative advantage in screening sale finance customers than conventional banks in screening borrowers because of the virtually non-existence of

\footnotetext{
${ }^{4}$ When present money is lent against future money, time preference in money becomes central. When goods are delivered against future payments, or present payments are made against future delivery of goods in Islamic finance, time preference would be related to the goods and not to cash balances. The implication is that different goods would command different markups, depending on their rates of time preference. Such markups would be equated at the margin under perfect competition.
} 
information asymmetry in the case of five out of six Islamic sale finance contracts.

Regulation must therefore be directed to establishing procedures for Islamic sale finance that would provide for the proper use the financed commodities as collateral until full repayment is concluded. When commodities cannot serve as collateral, because they are either perishable or with high cost of repossession, additional regulations must be set. This would include procedures for penalizing delinquency and verifying temporary insolvency.

As to Salam finance, the agricultural commodities designated for future delivery cannot be used as collateral. The ability of the finance user to deliver such commodities depends on how their price received in advance is used towards cultivating them. Information asymmetry is therefore associated with such contract. The bank purchasing goods through Salam needs to ascertain that the use of the advanced funds will lead to producing sufficient quantities to be delivered.

Screening investors is a process that goes beyond the verification of the ability to pay. Investors, whether they obtain finance through sale, or partnership (in product or profit), must prove the feasibility of their investment, because it influences their ability to recover the finance they obtain. In this respect, regulation of Islamic banks must ascertain that they are properly equipped with the abilities to prepare, review feasibility studies, and monitor investments made through Mudaraba and Wakala (investment agency). Monitoring would be done automatically with partnership in product and profit, because in both cases, Islamic banks participate in management and have direct access to investors information.

\section{MONITORING BANKS AND CUSTOMERS}


Banking theory focuses on the monitoring of borrowers' actions after loan approval. Models here have concentrated on one of the following (Freixas and Santomero, 2002).

1.- The actual use of borrowed funds (Boot and Thakor, 1993),

2.- Effort involved (Allen and Gale, 1988), and

3.- Ex post outcome revelation (Diamond, 1984, Gale and Hellwig, 1985).

In this context, Islamic finance monitoring of finance users' actions during the use of finance takes a different form. In partnership finance, an Islamic bank or financial institution, in its capacity as partner, is a part of the management ${ }^{5}$; information flows automatically into its hands. Regulations must therefore stipulate that the Islamic bank must ascertain that the finance user is properly equipped to collect and disseminate all necessary information.

In sale finance, an Islamic bank or finance institution would provide commodities, not cash, to finance users. Therefore, there is no need to worry about how funds are used. What remains is that the financier must ascertain through maintenance and insurance contracts that the use of commodities provided would not be contrary to their ability to be used as collateral ${ }^{6}$. Regulations must therefore provide rules against obtaining finance for commodities that would be automatically resold to others. Commodities, which cannot be used as collateral, because

5 That means membership in boards of directors of financed companies. The amount of partnership finance would be set by an Islamic bank in order to reduce the cost of monitoring to minimum. In other words, the share of the bank in the company should be large enough to afford it membership in the board of directors and continuous flow of information.

6 Consequently, an Islamic financial institution has direct interest in refusing to finance commodities for those who obtain finance for liquidity purposes, i.e., purchase goods for immediate resale, or Tawarruq. The ability of financed goods to serve as collateral would significantly diminish under such behavior. 
of their nature, should be given special treatment, like requiring guarantees or suitable collateral.

In contrast, Salam finance presents a need to monitor how the fund user utilizes the funds in order to finance the production of a sufficient amount of product for future delivery. This type of finance is marred with serious information asymmetry which must be confronted with either matching it with partnership finance or imposing special procedures to facilitate inexpensive monitoring7. The rules listed below for PLS and Wakala finance must therefore apply to Salam.

The question of how customers use funds after obtaining finance arises also in the cases of Amana or trust finance, which includes Mudaraba (profit-and-loss sharing, PLS) and investment Wakala (agency investment), both unrestricted and restricted. Therefore, it becomes necessary for Rabbulmal (fund owner) to insure against encroachment, negligence and violation of contract. Towards that end, regulations can set suitable guidelines for Amana finance (Mudaraba and Wakala) as well as Salam, including the following.

1. Making feasibility studies to estimate the expected or indicative rate of return, by whose figures and results the finance users must be bound, except for changes that occur for reasons beyond their power. In such case, the burden of proof falls squarely on the shoulders of the finance users.

2. The investment agent, Mudareb, managing partner, or Wakeel (investment agent) must hold orderly bookkeeping and supply audited financial statements

7 The need to exercise monitoring with Salam finance could be ignored because the contract does not stipulate the delivery of the goods to be cultivated, horticulture or even manufactured, but goods to be delivered must be chosen to be easily available in the market which the fund user can acquire and deliver. However, we think that the contract has been originally developed as a means to finance production of goods to be delivered. 
regularly (monthly or quarterly) containing the information necessary for proper monitoring.

3. Control of payables and receivables of financed operation must be done through an account with the bank or finance institution, where all outward movements would be approved by both the financier and the finance user.

4. To avoid such costly procedures, PLS, Wakala and Salam could be joined with Musharaka or partnership finance, where the bank is continuously informed about business developments in the financed company. Regulations should therefore accept that, as a substitute for the above procedure.

When it comes to monitoring banks by customers, we find that the incentive to monitor one's bank is rather week in conventional banking. This is because all deposits are presumed to be guaranteed under the classical loan contract, both principal and interest. Obviously, such guarantee is valuable only to the extent of which the occurrence of bank failures is not possible and deposits are insured.

Perhaps, monetary economists assume that since deposit insurance usually covers small-size deposits, those with large deposits can afford monitoring their banks. However, this still does not explain how this monitoring would be done. Besides, the mere dependence on the follow up of published financial statements and other data about the bank is not sufficient for effective monitoring. The question of how customers of conventional banks monitor their banks effectively remains to be answered. 
In Islamic banks, investment accounts are held under the rules of $\mathrm{PLS}^{8}$ and are not guaranteed ${ }^{9}$. Finance providers in this case are far less informed than finance users. Because of information asymmetry, they face the risk of moral hazard whose reduction requires monitoring. Investment account holders would have a strong incentive to monitor Islamic banks, but have no effective way to doing so. Regulation may fill out this gap by providing access to investment account holder to monitoring Islamic banks through enforcing a governance rule that appoints some of the holders with highest investment-account balances as members of the board of directors.

The rationale for such representation is that investment accounts face the same risks as shareholding in the bank. How much representation should be accorded to them? Proportional representation would make account holders a majority in banks' boards of directors. Meanwhile, considering that some of these accounts are transitory, regulations can set a criterion that considers both account size and maturity for the eligibility to sit on the board.

Obviously, with most investment accounts maturing at the end of the financial year, holders of investment accounts can become a majority in the Board of Directors. A new type of a banking establishment, managed by "depositors" could arise. Islamic banking would be radically changing its institutional structure and moving further away from conventional finance.

\footnotetext{
${ }^{8}$ Some also can be held under Musharaka and Wakala, which would equally require monitoring.

9 In some developing countries, all deposits are guaranteed by the government. This introduces an element of moral hazard in banking, balanced by the power of monetary authorities to monitor banks through regulation and supervision. The monetary authorities would monitor banks on behalf of customers, hence. Sometimes, the monetary authority limits the risk each bank is allowed to take. This would introduce an element of inefficiency in the banking sector.
} 


\section{LIQUIDITY RISK INSURANCE \& MATURITY MISMATCH}

The justification of providing guaranteed deposits, offered by Diamond and Dybvig (1983), assumes uncertainty of consumption timing. Conventional banking contracts allow for some ex ante insurance. Despite the possible instability of conventional banks, their guaranteed deposit contracts are preferred to financial securities (McCulloch, 1986).

The provision of guaranteed, instead of PLS deposits returns the financial system to the prisoners' dilemma. If all holders of "investable balances" were to be provided with guaranteed deposits, risk would be borne by only one side of the financial system, namely, fund users. Lack of coordination would deprive the system from the compactness associated with system-wide risk sharing, whose benefits would outweigh the private benefits accruing to each individual depositor.

Both conventional and Islamic banks mobilize resources which are mostly short-term through accepting deposits or investment accounts. Yet, they require longer-term funds in order to provide loans to conventional bank customers and make profitable investments by Islamic banks. Maturity mismatch is therefore a common hazard of the banking industry.

Regulations attempt to protect conventional banks from maturity mismatch through ascertaining that each has a viable system of liquidity management that assigns to each future payment to be made, a matching sufficient inflow that cover it over the short- and medium-term. This can also be done in the case of Islamic banks.

Another means is to securitize investment accounts by issuing investment certificates of long maturities that can 
be sold by their holders before maturity. This adds liquidity and flexibility to investment accounts, similar to certificates of deposits in conventional finance.

A third means is to finance long-term projects through Sukuk. The sale of Sukuk would bring in sufficient proceeds to finance the project. In addition, Sukuk would be tradable, which affords their holders a good measure of both liquidity and return.

Islamic banks do accept demand deposits like conventional banks. Their assets, too, have longer maturity than their demand deposits and investment accounts. However, they have more tools to use in bridging the maturity gap than do conventional finance. In particular, they can apply the following methods:

1. The use of restricted investment accounts, based on restricted PLS or Wakala, to attract funds directed to financing certain projects or portfolios with maturities longer than available through unrestricted investment accounts. This enables Islamic bank to earmark the proceeds of some restricted investment accounts to certain long term investments. It would be an effective means to mobilize funds with maturities that exactly match the maturity of assets to be created. Naturally, the rate of return on accounts with longer maturities would be sufficiently convincing. In contrast, conventional finance does not have access to attracting restricted Wakala and PLS accounts.

2. Securitization of long-term projects, portfolios and syndicated finance into Sukuk of long maturities to attract funds with longer maturities. This enables Islamic banks to establish the exact match between their assets and liabilities. It is notable that Sukuk transfers the title to the securitized assets from banks to Sukuk holders, which provides an effective way to 
match maturities. Meanwhile, the use of securitization of some of their assets by conventional banks does not transfer titles to the assets to security holders. Conventional banks remain stuck with the titles to their assets. Maturity mismatching relief would therefore be limited.

3. Securitizing investment accounts into PLS and investment Wakala Sukuk of various maturities in order to make them liquid to depositors. Trading investment account Sukuk will allow investment account holders to exit without deposit withdrawal. This affords the Islamic bank an opportunity to turn investment accounts into negotiable investment certificates of long maturities (that can be sold by their holders before maturity). This adds liquidity and flexibility to investment accounts, similar to certificates of deposits in conventional finance.

Regulations must therefore set rules for the holders of restricted investment accounts in order to allow them some monitoring rights with regard to the projects, funds or portfolios in which they invest. In addition, proper procedures must be set for securitization into Sukuk, in order to insure that Sukuk holders control the special purpose vehicles and not banks or Sukuk issuers. The true sale of securitized assets must be effected in order to ascertain their title transfer to Sukuk holders. This would effectively remove those assets from banks balance sheets. In addition, regulations must set proper rules for trading such Sukuk in primary and secondary markets in coordination between monetary and financial market regulators.

\section{CREATING A SAFE ASSET.}

Gorton and Pennacchi (1990, 1993) consider banks as an optimal security design. Bank deposits provide an 
investment in a safe asset, which is not affected by information in the financial markets and is a feasible, efficient asset in optimal portfolio decisions.

Yet, such security leads to concentration of risk in the hands of few specialists, namely bankers. Deposits in conventional banks are loans guaranteed both principal and interest. Such guarantees influences banks behavior. When banks face higher risks, they tend to transfer a larger share of risk to their customers through higher interest rates (Tovar, Jaramillo and Hernández, 2011). At times of crises, the increased vulnerability of the system leads banks to fear bank-runs started by one of the banks going bankrupt. Their competitive drive is attenuated by their interest in protecting their "fellow banks" from failure. Financial crises, therefore, reduce banks' incentives to compete, and induce them to use crises as coordinating signals for collusion. That is why they are capable of raising the interest rates charged to their customers.

The experience of the 2008 international financial crisis has clearly shown that the multiple layers of deposit guarantees by banks and insurance agencies do not play an important role in creating a safe asset. The way monetary authorities handled the crisis ended up with dipping into taxpayers' pockets to bail out banks. Safety or rather lack of it seems to be intertwined with the behavior of bankers, and their inability to resist temptation to give in to moral hazard.

Islamic banks guarantee only demand deposits. The risk is fully borne by Islamic banks themselves. Because they guarantee the repayment of demand deposits, they allow themselves to invest a proportion of them in the PLS asset 
pool ${ }^{10}$. Shareholders money and (unrestricted) investment deposits are invested side-by-side in that pool. This in turn places limits on the risks taken for the whole pool, as banks' shareholders automatically share a part of this risk. The tendency to fall into moral hazard is not significantly reduced due to the participation of shareholders in the Mudaraba pool. As such, banks' share would be a small proportion, leaving the lion's share to investment deposits.

The behavior of Islamic banks towards bearing risk stands in contrast with that of conventional banks. During financial crises ${ }^{11}$, the risk carried by Islamic banks and investment account holders increase. Islamic banks do not shift part of their risk to investment account holders by reducing the profit-sharing ratio assigned to the latter. Instead, we find that the rate of return earned by both parties becomes lower.

In order to maintain competitive profit rates on investment accounts, Islamic banks may decrease their own profitsharing ratio in favor of their customers. Other direct cushioning devices are used, like withdrawal from the profit stabilization reserve and the investment risk reserve in order to prop up the profit rate distributed to investment accounts.

This, however, does not mean that profits distributed to investment account holders do not fall during crises. We have noticed that such rates did fall significantly during the latest international financial crisis. This can be related to the exercise of extra care by Islamic banks or the dearth

10 This is the collection of assets in which Islamic banks invest its shareholders' money together with a discretionary proportion of demand deposits and all (unrestricted) investment deposits.

11 Financial crises can strike Islamic finance in mixed financial systems. This can be attenuated by the availability of financial assets that facilitate interbank deals among Islamic banks. In a purely Islamic finance system, the possibility of crises is removed by the virtue of the absence of risk trading and the strong binding of the financial with the real sector. 
of profitable investment opportunities rather than moral hazard.

Still, there is a need to bar Islamic banks at times of crises from shifting risk to their customers and to strengthen the banking system against the temptation to moral hazard. This may require few steps to be taken by regulators. The first step is to make sure that each Islamic bank has sufficient resources in the form of direct cushions. Rules for setting aside a proportion of profits earned at good times to be used in topping up such cushions could be one of the ways to do so.

The second step is to make sure that Islamic banks provide a rate of return on investment accounts that is higher than the interest rate paid by conventional banks on time and saving deposits to compensate investment account holders for the extra risk they take in financing real economic activities instead of providing collateralized loans ${ }^{12}$. It is rather anomalous, yet common, for Islamic banks to pay a rate of return on their investment accounts that is not significantly different from the rate of interest paid out on conventional deposits. Reasons for such phenomenon can be found in the tendency of Islamic bankers to mimic the financial products offered by conventional banks, after dressing them into an Islamic attire. This would lead to the convergence of rates of return in both Islamic and conventional banks.

Perhaps, we can detect some degree of negative moral hazard on the side of Islamic banks. Islamic banks may have gone too far in mimicking conventional banking by evading the tradeoff between risk and return and focusing on sale finance, where collateral can be easily obtained.

12 The nominal rate of growth of the economy could be used as a benchmark to the rate of return on investment. If an Islamic bank is not distributing the benchmark as a minimum, its operations should be scrutinized to check whether the Islamic bank in question is placing some of its resources in conventional outlets. 
Meanwhile, finance based on partnership in product and profit may be willfully avoided. This will be dealt with later with more regulatory tools, as it involves several other ramifications.

\section{SECTION III: INCENTIVES TO MONITOR AND ASSET SAFETY}

Monitoring distinguishes German universal banking from Anglo-Saxon commercial banking. It also distinguishes conventional from Islamic banking, should Islamic banks be true to their own paradigm and act like universal banks. Monitoring also distinguishes banking loans, which are presumably subject to monitoring from tradable debt (bonds) which are not.

Monitoring can be done in two directions: banks monitoring their customers (finance users) and depositors or investment-account holders monitoring their banks. Optimality requires that monitoring be exercised both ways. However, the incentives to monitor are not always present on both sides. Obviously, universal banks have a greater incentive as well as the effective tools to monitor their customers. However, the extent and effectiveness of such monitoring has been debatable (Baliga and Polak, 1995) ${ }^{13}$. This ultimately depends on the extent to which universal banks take equity in the companies to which they provide finance. Active membership of universal banks in their customers' boards of directors and the degree of their involvement in management sets the borders of such monitoring.

The relationship between universal banks and firms have been subject to much scrutiny. Some authors report substantial monitoring as old as early Twentieth Century

13 The debate has continued since the date of this article in 1995. See for example, 23. Elsas and Krahnen, 2003. 
(Hilferding, (1910); Riesser (1909)). Fohlin (1993), meanwhile, argues that banks representation on boards was much lower before 1900. In addition, Edwards and Fischer (1994) as well as Edwards and Ogilvie (1995) argue that the influence of such boards both past and present has been exaggerated.

This author has previously claimed in other writings that universal banks are well placed to monitor their customers, based on the presumption that such banks are allowed to take equity in the firms to which they provide financing in the form of conventional loans. The fact is that such assumed practice is not always the case. In many cases, German banks sat on firms "supervisory board", an institutional organ that has a vague role, which is different from the firm's "board of directors" that represents equity shareholders in the firm and does the actual management, (Guinnane, 2001). We now realize that German banks have had a complicated relationship with business and cannot simply be assumed to behave like equity-holders in customer firms.

However, our main assertion remains. If a conventional bank is allowed to provide finance in the form of equity in addition to conventional loans, information asymmetry attached to the conventional loan vanishes and the bank is automatically freed from the risks of adverse selection and moral hazard. The lesson learned from such assertion is that universal banking as we perceive it, is an effective way to eliminate information asymmetry. Islamic banks use 16 finance and investment contracts six of which suffer from information asymmetry. The paradigm of Islamic banking should therefore include operating like a 
universal bank that takes equity in the businesses they finance ${ }^{14}$.

Monitoring is therefore critical to both Islamic and conventional banking, simply because it eliminates information asymmetry. Such elimination removes the risk of adverse selection and moral hazard faced by customers providing deposits or investment accounts to banks, and by banks providing finance to customers.

Therefore, we can conclude that the quality of assets held by banks through financing activities and of assets held by the public through placing deposits or investment accounts with banks, depends upon the incentive of banks and customers to monitor each other. Optimality requires Pareto optimal incentives for banks to screen, monitor and invest and for customers to monitor banks with which they place funds. With incorrect incentives, market failures in the banking industry will occur, reducing social welfare and real economic activity (Gertler, 1988). Such problem can be remedied with proper regulation as explained below.

\section{BANKS AND CUSTOMERS' INCENTIVES TO MONITOR.}

Conventional banks incentives to monitor borrowers do not come naturally through the market mechanism. Lack of conventional banks' incentives to monitor emanates from their use of the classical loan contract and their resulting insistence to limit their risk-taking to the risk on collateral. To provide them with incentives to monitor requires a radical change in their behavior that would turn them to assuming some degree of business risk.

${ }^{14}$ We must remember that equity finance is the same as Musharaka and diminishing Musharaka, which are two of the Islamic finance sixteen contracts. 
Holders of demand and time deposits with conventional banks have little incentive to monitor their banks, as their deposits are guaranteed in principal and interest by banks as well as fully or partially insured by deposit insurance schemes. They can be induced to monitor their banks only if the classical loan contract is no longer the basis for providing such deposits and if deposit insurance coverage is limited to small deposits.

In other words, introducing incentives to monitor into conventional banking by both banks and deposit holders would require systemic changes. This would call for the discussion of banking reforms, which is beyond the scope of this research.

The safety of assets held by Islamic banks will generally depend on their underlying Islamic finance and investment contracts, investment feasibility and safeguards to insure transparency and disclosure.

Islamic banks practices indicate their preference to sale over partnership and agency-investment finance. When an Islamic bank provides sale finance, it does not give cash to customers, but rather purchases merchandise and assets and provides them to customer. Only in the case of Salam or deferred-delivery sale that cash is advanced against later delivery. This means that, except for Salam, sale finance includes a self-monitoring mechanism. Sale finance is therefore free from information asymmetry and requires no extra monitoring beyond its self-monitoring mechanism ${ }^{15}$.

The choice of the underlying Islamic finance and investment contracts provide Islamic banks a unique

15 One exception needs to be mentioned, that regulators must set conditions for the resale of financed assets before full finance repayment, in order to make sure that the quality of banks' collateral will not deteriorate due to premature sale, which is usually practiced under Tawarruq. We propose as a condition that the new buyer would pay all remaining installments in full 
opportunity to create assets with self-monitoring mechanism. There is a menu of sixteen finance and investment contracts from which to choose. Each contract has a different degree of embedded risk, depending on its implicit monitoring. Mixing and matching contracts, or what is commonly known as product structuring, can be an effective method to sculpture quality assets.

Joining PLS, Salam or Wakala, which has no selfmonitoring mechanism with Musharaka or diminishing Musharaka, with their powerful self-monitoring mechanism, in one product would significantly reduce information asymmetry and its related risks ${ }^{16}$. Risks of Musharaka itself can be mitigated through joining it with Ijarah. The size of the menu of Islamic investment and finance contract indicates that the number of products can go into several hundreds.

To benefit from such advantage may require proper regulation. Islamic bankers, interested in short-term objectives and being aware of their inability to internalize the external benefits of Islamic finance may shy away from using certain contracts, particularly those of partnership in profit and product, like PLS and Musharaka. Therefore, regulators have to make sure that Islamic banks under their supervision use the art of product structuring to its full potential.

This can be handled through considering that failure to use product structuring effectively can be a source of operating risk. Regulations must therefore ascertain that each Islamic bank has sufficient resources and proper procedures to structure Islamic finance products. In addition, supervision should review samples of previously

${ }^{16}$ Notice the similarity of this approach with that is supposedly used by universal banks (A1Jarhi, 2001), when they actually provide equity finance side-by-side with conventional loans. 
structured products to test for their propriety and their ability to fulfill customer objectives and bank goals.

We can therefore conclude that the classical loan contract stands as an obstacle against motivating conventional bankers and depositors to monitor each other. Such motivation requires a systemic change to provide an alternative to the classical loan contract. Meanwhile, Islamic banks require regulatory discipline to force an imaginative effort towards mixing and matching among the sixteen available Islamic finance and investment contracts.

\section{CUSTOMERS' INCENTIVES TO MONITOR AND ASSET SAFETY}

We mentioned above that customers in their capacity as depositors and investment-account holders have little incentive to monitor their banks beyond comparing interest rates paid by conventional banks on deposits, rates of return paid by Islamic banks on investment accounts as well as other banking services. This deprives customers from early-warning signals indicating the imminent collapse of their banks.

Deposits in conventional finance are defined as loans from customers to banks. The conventional loan contract makes banks liable to depositors to repay their deposits and accrued interest in full. While it is generally understood that all loans, albeit in different degrees, are subject to default, depositors do not have sufficient incentives to continuously assess the default risk of their banks. Again, we find that in order to create the proper incentives to monitor, customers must place their funds with banks on a basis that is different from the classical loan contract. This as mentioned above begs the question of bank reform. 
Customers of Islamic banks who deposit their funds in investment accounts have a different position. First, their investment account is placed on the basis of profit-andloss sharing. No guarantee is therefore implicit. Second, despite the similarity between the positions of investmentaccount holders and bank shareholders, the latter have an effective way of monitoring their bank by electing its board of directors and looking into their audited financial statements every financial year, while the former have no way whatsoever. They must therefore rely on the monetary authority for monitoring their bank. Past recurrence of bank failures indicate that the monetary authority monitoring is not sufficient to protect investment account holders.

Regulations must therefore provide the means for customers monitoring of banks. The mechanism we propose should be similar to that assigned to shareholders. That is to insure that depositors would be represented in the board of directors in proportion of their deposits (or investment accounts) to the total funds invested by the bank. In order to do so, we must assign a number of seats in the board to depositors. Then, we select those who should occupy these seats from the top investment-account holders, considering their investment account balances and their length to maturity.

\section{SECTION IV: MARKET FAILURES AND REGULATION}

There are three sources of market failure: the presence of public goods, externalities and monopolies (market power).

\section{PUBLIC GOODS AND REGULATION}

The banking and finance system itself, once established, renders benefits to all users, like the provision of a means 
of exchange and the use of monetary policy, in order to gauge monetary growth to the requirements of economic growth and to control inflation. There is no way to apply the exclusion principle to all beneficiaries. Of course, banks can charge for their services, but cannot charge for the benefits from their mere existence. The monetary authority itself cannot charge individuals who happen to gain from monetary policies. Taxes must ultimately be used to cover the costs of establishing, maintaining, regulating the banking system and managing monetary policy.

Does banking and finance in general contain an element of public goods that justify its regulation? Would that apply equally to both conventional and Islamic finance? How would regulation provide a reasonable solution to the public good problem in both cases? These are the questions into which we would like to look.

\section{A. THE PUBLIC GOOD ELEMENT IN CONVENTIONAL BANKING}

If we excluded the mere existence of the financial system as a whole, financing services provided by banks are not pure public goods, as the exclusion principle can easily be applied to conventional finance. The existence of banking complements the institution of money by providing monetary services, like accepting deposits, organization of payments (transfers, clearance, etc.). Regulation of banks preserves the quality of banking services and monetary policies preserve the quality of real balance. Such benefits are not subject to the exclusion principle and must be financed through taxation.

Conventional finance is provided, based on creditworthiness and collateral. In addition, the conventional banking system is associated with some 
public bads. Those result from the use of the classical loan contract (Al-Jarhi, 2001).

- Finance through the classical loan contract causes the allocation of resources to be based on "lending criteria" rather than "investment criteria" (Al-Jarhi, 2001). Since the size of the debt to be repaid would be subject to cumulative interest, debt can augment indefinitely and ultimately become unsustainable. The financial sector would experience an enormous amount of innovation in the field of risk trading, causing it to be remotely connected to and much larger in size than the commodity sector, ultimately resulting in the lack of compactness of the economic system.

- A conventional bank or financial institution is inherently unstable. Its liabilities are guaranteed both principal and interest, while its assets are subject to default risk.

- A positive interest rate, guaranteed to be paid, on loans encourages the substitution of real resources for money in transactions, thereby reducing efficiency.

- Information asymmetry exposes commercial banking to risks of adverse selection and moral hazard. Mitigation of such risks require expensive monitoring or the switch from commercial to universal banking (Al-Jarhi, 2005).

- Financial innovations through the use of risk trading exposes the economy to instability and contagion.

- In a democracy with imperfect information, bank size becomes a critical element in economic policy, giving rise to the claim that some banks are too big to fail. Policymakers tend to draw taxpayers' money to subsidize them during crises (Al-Jarhi, 2009). 


\section{B. THE PUBLIC GOOD ELEMENTS IN ISLAMIC BANKING}

The Islamic banking and finance system would have the same elements of public goods as its conventional counterpart, namely the provision of a means of exchange and monetary policy. In contrast to conventional finance, Islamic finance has a much lower share of public bads, as seen below.

- Islamic banking and finance, properly applied allocates resources according to investment rather than lending criteria. In addition, the size of debt (associated with sale finance) would be predetermined at the outset and not subject to increase. Debt would therefore be sustainable ${ }^{17}$. The financial system would be closely connected to and smaller in size than the real sector. Therefore, the economic system would be compact ${ }^{18}$.

- An Islamic bank or financial institution has no guaranteed liabilities, with the exception of demand deposits. Compared with the presence of risks associated with its assets, it appears to be more stable than a conventional bank or financial institution. In addition, sale finance of assets (provision of commodities on credit) automatically provides for sufficient collateral. Asset creation by Islamic banks would therefore involve an element of risk selfmitigation that is not automatically available to conventional finance.

- Return on Islamic banks investment accounts is not

17 Temporary insolvent debtors would be provided rescheduling at no extra charge or increase in their debt. Only in cases of delinquency, debtors are subjected to penalty fees, which are given to charity and not transferable to banks.

${ }^{18}$ We are assuming a monetary structure, where all money issued is placed by the central bank into central investment accounts and the central bank has an exclusive monopoly on money creation. In addition, banks provide finance only through the sixteen Islamic investment and finance contracts Al-Jarhi 1983. See Appendix III. 
guaranteed, providing no incentive to substitute real resources for cash in transactions. The system would therefore stay efficient ${ }^{19}$.

- Ten out of the sixteen Islamic finance and investment contracts enjoy perfect information symmetry between finance providers and users. Only PLS, Salam and Wakala (restricted and unrestricted) contracts are subject to information asymmetry. Their use in conjunction with Musharaka would be an inexpensive way to provide perfect monitoring.

- Islamic finance is prohibited from innovating through risk trade. Innovation comes as a result of introducing new products through mixing and matching of the existing sixteen contracts. An important source of instability and contagion is removed from the financial system, hence. However, innovation can lead to finance products of ill repute ${ }^{20}$. They would be instrumental in converging the Islamic finance system to conventional finance, thereby depriving the former from its important comparative advantages. In this respect, we find room for regulations to prevent slippage into products of ill repute.

- The rise of large banking units in societies using Islamic finance is still possible. Whether this can be used to support the claim that such large banks are too big to fail, will depend on the game-theoretic

19 When the return on deposits is guaranteed, as in the case of the rate of interest, people are tempted to economize on holding cash for transactions purposes by substituting real resources for cash in transactions. This brings the economy down to a suboptimal level of output. In an Islamic economy, there is no guaranteed return on cash balances. Investment accounts are provided on a profit-and-loss-sharing basis. There would be no incentive to substitute real resources for cash in transactions.

20 Islamic finance products of ill repute result when Islamic banks attempt to use conventional finance products after dressing them into an Islamic garb, like 'Einah, Tawarruq, and products based on the sale of debt. The author coined this term to refer to such products that appear Islamic but are truly conventional, or those that fulfill the formal validity of the contracts used, but violate the General Objectives of Shari'ah or Maqassed AlShari'ah. 
structure of the political system ${ }^{21}$. However, using tax money to provide fund users with temporary illiquidity during crises through debt rescheduling instead of directly subsidizing banks would prove more effective in avoiding both recessions and bank failures simultaneously. While this coincides with the teaching of Islam, it requires regulations to direct the regulators' attention to providing relief to insolvent debtors, penalizing the delinquent and prohibiting direct subsidies to banks.

\section{REGULATION AND MONITORING}

\section{A. REGULATION AND MONITORING IN CONVENTIONAL BANKING.}

Regulation by itself cannot remove the public bads described above from the system of conventional banking and finance. They turn to be systemic ills that require modifying the system.

Regulation can do little in reducing information asymmetry that is associated with the classical loan contract. However, regulation can enforce monitoring by both conventional banks and their depositors. Since in both cases "loaned" cash is provided to one party to use in some fashion, monitoring would require some changes in the rules of the game. An example would be project finance, where regulations would require dividing projects into stages and providing loaned cash in installments, each disbursed upon the completion of a specific stage ${ }^{22}$.

\footnotetext{
${ }^{21}$ Whether democracy practiced under Islam (e.g., as in Indonesia, Malaysia, Senegal, Tunisia, and Turkey) would also be associated with strong interest groups and large-size banks will depend on many political factors that are beyond our scope. However, constitutions used as bases for democratic rules in countries where Islamic values are held, can be tailored to minimize the influence of interest groups.

${ }^{22}$ Such procedure would be similar to the one used in conjunction with Istisna' contract.
} 
However, setting procedures for monitoring finance users while using the provided finance would make conventional finance cumbersome and costly. This would negate the benefits of using the classical loan contract resulting from its simplicity. It would of course be better to choose one or more Islamic finance contracts that would be free from information asymmetry instead of the classical loan contract. However, financial innovation has not been known to go into that direction.

As to the monitoring of banks by depositors, a possible proposal that depositors would be represented in the boards of directors of conventional banks in proportion of their deposits to total resources. This can hardly be justified, since depositors provide deposits as "loans" guaranteed to be repaid both principal and interest.

In addition, as deposits usually exceed paid up capital by many folds, giving depositors a share in bank management would change the character of conventional banks radically. In itself, such action would be a serious institutional change and not merely a regulatory action.

Generally, banks cannot effectively monitor the finance users unless money is not given in cash, but used jointly by both banks and customers. This, in turn, would be a serious institutional change.

The conclusion is that regulation itself is not sufficient to induce both conventional banks and their customers to monitor each other. The optimum amount of monitoring in the conventional banking system cannot be reached without forsaking the concept of the classical loan contract. 


\section{B. REGULATION AND MONITORING IN ISLAMIC BANKING.}

Since Islamic finance does not rely on the classical loan contract, it would be easier to fine-tune monitoring to the optimum level through regulation. In this regard, regulation can help Islamic finance in the following areas:

1. Placing guidelines for the use of Amana finance, through the contracts that provide cash to finance users, namely, PLS, Salam and Wakala, in order to facilitate their use, in conjunction with Musharaka. Such guidelines which have been outlined in section II above, would reduce the extent of information asymmetry imbedded in PLS and Wakala.

2. To prevent products of ill repute, regulations must clearly define all Islamic finance products and currently prevalent non-compliant products (of ill repute) ${ }^{23}$ and establish a Shari'ah supervisory board in the regulatory and supervisory agency, while doing away with Shari'ah boards in Islamic banks. The presence of a Shari'ah board within the regulatory and supervisory agency would then be sufficient, once definitions of Islamic finance products, permissible and non-permissible, have been added to banking, commercial and financialmarket laws.

3. In line with the above proposal, each Islamic bank can maintain a special department for product structuring that employs people with proper expertise. The department would configure the financing deals provided to customers, using a combination of the sixteen Islamic finance and investment contracts to satisfy customers' requirements while maintaining

23 It is also important to add such definitions to the banking law, financial markets law and civil law to facilitate litigation regarding conflicts between parties involved in Islamic finance and to reduce reliance on religious interpretation. 
economic feasibility.

4. The meaning of compliance of Islamic finance products should be extended to include the non-violation of Maqassed Al-Shari'ah or the objectives of Shari'ah, in economics. This means that transactions must be valid in both form and objectives. Objectives here refer to the ultimate consequence of transactions. For example, transactions that are formally valid (satisfying the required contractual form), can still be non-permissible if they lead to unemployment, inflation, instability or inequity or violate the ethical standard of Islamic investment ${ }^{24}$.

\section{REGULATION AND SAVING BANKS FROM BANKRUPTCY}

Monetary authorities in conventional economic systems have been accustomed at times of crises to save banks from bankruptcy, usually starting with big banks. The reason is the fear that the demise of one bank could trigger a domino effect on the whole banking system. Such process implies huge transfers from taxpayers to banks' shareholders. In this respect, larger-size banks enjoy a higher priority in obtaining such subsidies. Such policy often protects banks from bankruptcy. However, it provides no protection to the economy from recession, as banks during times of crises have relatively conservative lending policies.

In Islamic banking, the protection of banks from bankruptcy remains a legitimate objective. However, Islamic banks, properly managed, ought to show more resilience than conventional banks. This is due to the different nature of their balance sheets. While Islamic banks assets are subject to investment hazards, their

${ }^{24}$ Such standards include in addition to dealing in interest, risk trading and cheating, human trafficking and inflicting harm on life or environment. 
liabilities are not guaranteed because investment accounts are usually based on PLS or profit-and-loss sharing, PLS.

Regulations can prohibit providing direct subsidies to banks that face bankruptcy risks. Instead, they should offer assistance to customers who face temporary insolvency at times of crises in the form of rescheduling. In addition, they should impose substantial penalties on delinquent finance users ${ }^{25}$.

At times of crises, subsidizing banks to prevent their bankruptcy would not encourage them to keep providing financing economic activities at the same pace. Reduction in financing would push the economy down into recession. However, if insolvent borrowers obtained rescheduling breaks, they would be able to repay their debt, albeit at a longer period and with lower rates of return to banks. Aggregate spending will not be seriously affected, banks will not face bankruptcy and the economy will not fall into recession (Al-Jarhi 2008).

Obviously, such proposal will involve no wealth redistribution between tax payers and banks shareholders. To the contrary, banks shareholders may face a slightly lower rates of return because of forced rescheduling on temporarily insolvent customers.

\section{SECTION V: RELATED ISSUES OF MONETARY POLICY}

\section{FORCED WEALTH REDISTRIBUTION.}

25 The distinction between temporary insolvency and delinquency is central to this proposal. Temporary insolvency can be perceived as a shortage of present cash that prevents debtors from meeting their payment obligations. Delinquency implies an intentional refusal to pay one's financial obligations in order to spend the currently available cash on something else. 
In conventional finance, banks as monopolies are implicitly allowed by law to create money collectively in the form of derivative deposits. Such a permission is granted by default through the fractional reserve system. The process of money creation through derivative deposits is a result of collective behavior and not that of a single bank.

Such money creation imposes an externality on the nonbanking public. Money collectively created by banks is lent to customers at an interest rate. Charging interest on lending is rationalized by the fact that money has transactions services. Yet, such services emanate from the fact that money is generally accepted as means of exchange by the public ${ }^{26}$.

Since the public is the source of general acceptability, it should earn any return resulting therefrom. Nonetheless, such reward, which is the source of monyness, does not go to the public. It goes to banks instead. Therefore, conventional banks force a redistribution of wealth to their favor through their creation and lending of money in the form of derivative deposits.

The provision of the money issued by banks as interestbearing loans imposes another externality. The underlying classical loan contract suffers from information asymmetry and imposes on the whole society extra risks of adverse selection and moral hazard. Such risks ultimately lead to an aggregate level of output below optimum. As explained above, risk-sharing would be a better arrangement for the whole economy. However, lack of coordination between economic agents forces them to stick to continue to use the interest-rate mechanism.

${ }^{26}$ Notably, outside money issued by the monetary authority (the monetary base) is usually a small fraction of the money supply. Banks collectively can create a multiple of the monetary base in terms of derivative deposits. The wealth redistributed from the public to banks' shareholders is proportionately high. 
Regulation has only one way to internalize such externalities to the benefit of the whole society. Regulators, through the enforcement of total reserves, give the monopoly of issuing money total and complete to the monetary authority.

In both of an Islamic and a conventional economy, the application of the total reserve system prevents wealth redistribution from the public to banks' shareholders. However, it will not insure against information asymmetry in a conventional economy. In both Islamic and conventional economies, the total reserve system may not be sufficient. Guidelines must be set on the proper disposal of seigniorage gained by the monetary authority.

\section{FORCED HIDDEN TAXATION}

In conventional banking, the monetary authorities issue the monetary base against government debt. The interest paid by the government to the monetary authority on its debt returns to the government in the form of monetary authority surplus. This means that the government obtains free financial resources at the expense of the whole society. The cost of such resources would be equivalent to a hidden tax that facilitates government sector expansion at the expense of the private sector. The tax would be approximately equal to the resulting increase in the rate of inflation. This is similar to the crowding-out effect that is accompanied by an inflation tax.

It is notable in this regard that the expansion of the public sector through borrowing from the monetary authority is a political decision that more often than not does not satisfy the efficiency criteria. The crowding-out effect would ultimately imply an element of inefficiency; unless competition is assured between the public and the private sectors, the allocation of resources will remain suboptimal. 
We can therefore propose that the expansion of the public sector by political decisions should be limited to activities that cannot be provided at a price, i.e., for which the exclusion principle cannot be applied. Moreover, government activities that can be provided under the exclusion principle should compete with those provided by the private sector on equal basis. Such competition can be assured when government activities of this type are financed through banks, where banks allocate financial resources among different activities using economicfeasibility criteria.

Additionally, transparency rules can be introduced. Government budget should add all items of seigniorage to "non-tax revenues" for which the government would be accountable. For the sake of transparency, such items should not be lumped together in one figure but duly itemized.

As to public goods, where the exclusion principle cannot be applied, taxation (with representation) would be used. In addition, the establishment of Awqaf, the collection and disbursement of Zakah and other charities should be facilitated, in order to lessen the need for government provision of public services.

\section{HOW THE NEWLY ISSUED MONEY IS USED}

Some may argue for giving all monetary balances issued by the monetary authority to the government in the form of interest-free loans. This begs the question of how to allocate economic activities between the public and the private sectors. Efficiency may require the use of market mechanism jointly with democratic political rules for such a division. Providing the government with free monetary balances may bias such resource allocation at the outset in favor of the public sector. 
We have to find a different way to dispose of the newly issued monetary balances, whose issue and allocation to different uses can be based on efficiency criteria and not merely lending criteria. Al-Jarhi's model (1981) has two distinct proposals in this regard.

First: the monetary authority should follow up the real growth of the economy and gauge any issued (or destroyed) money to the monetary requirements of real growth. The reason is rather obvious. Growth indicates higher output, requiring a larger size of transactions to produce and trade the expanded volume of goods and services. When more transactions are required, more monetary balances would also be required to conclude the necessary transactions, if the rate of inflation is to remain constant.

How much more money should be issued to support a rise in real growth by one percent? This question can be answered by the close follow-up of how the rate of inflation responds to a higher rate of monetary expansion. The monetary authority would learn from experience and discover how to gauge monetary expansion to the transactions requirements of growth, without causing inflation ${ }^{27}$.

Second, Al-Jarhi's model proposes a different way to dispose of monetary balances. In this model, the monetary authority adds to the total money supply by issuing money and placing it in investment (deposits) accounts with banks. Such central deposits would be allocated among banks according to efficiency criteria, where banks that are more profitable would obtain relatively higher proportions of central deposits. Perhaps the monetary

${ }^{27}$ Notice that in this model, the issue of money would not be politically influenced and price stability would be assigned a higher priority than it obtains in a conventional economy. In addition, monetary-policy makers would have more power to control both monetary expansion and the rate of inflation, as they hold absolute monopoly on the production of money, rendering it the highest degree of independence from political influences. 
authority would attempt to equate the rate of return from its central deposits in different banks at the margin.

In the absence of fractional reserves and the discount window, and in order to provide a financial instrument to serve as a tool for monetary policy, the monetary authority can issue central deposit certificates, CDC's as financial instruments, which both banks and the public can hold and trade. Such equity-based instruments can be used as a tool to change the money supply through open market operations, and to provide banks with temporary liquidity as part of the monetary authority function of acting as a last-resort provider of liquidity to banks.

The monetary authority would gain profits from placing its own central deposits with Islamic banks and acting as a first-tier Mudareb for the proceeds of central deposit certificates. This would be considered seigniorage whose disposal would be subject to transparency rules. The monetary authority surplus is balanced by banks' providing finance both to the government and to the private sector through market mechanism on equal terms ${ }^{28}$.

\section{THE MARKET MECHANISM}

In comparison with the banking sector in an Islamic economy, the conventional banking system has some distinct characteristics. Banks gain monopoly power through licensing. In addition, the banking system becomes a price setter, as the monetary authorities set the

\footnotetext{
${ }^{28}$ An important aspect of the Islamic economy is that social action determines the size of the public sector. Redistribution of wealth is done yearly through the levy of Zakah on those whose wealth exceed a certain limit. The redistributive branch of the economy can be privately managed but government controlled. Awqaf (or charitable foundations) can be established to provide for many public services, including health and education. The size of the public sector will be influenced by the extent to which the public is interested in providing public services through Awqaf, which has a special religious significance, but unfortunately, its role has been curtailed by modern governments in the Islamic world. In other words, an Islamic economy would be less encumbered with a government-budget deficit.
} 
rates of interest, which are used as bases for pricing loans. Conventional banks income on lending comes from the interest differential that may not change much with the level of interest rates set by the monetary authority ${ }^{29}$. The cost of funds is not therefore, market determined. This introduces an element of inefficiency to the finance system.

Lifting the monetary authority control on interest rates in a conventional economy would not be acceptable. Interest rates are considered an important policy tool that monetary authorities would not conceivably yield.

In Islamic banking and finance, funds are provided through the provision of goods and services on credit as well as through partnerships and investment agency. The rate of return on financing is market determined. Monetary policy is exercised exclusively through changing the monetary base and by open market operations in Islamic financial instruments.

Investment certificates, or as currently known as Sukuk, properly defined, can be issued in this economy by Treasury to obtain financing for its own projects. The monetary authority issues its own Sukuk as mentioned above. Banks and business enterprises can also issue their own Sukuk as a means to obtain financing through financial markets.

It is theoretically possible that the monetary authority would attempt to set the rates of return on these Sukuk (markup, rental and profit rates) through open market operations in each kind of certificates. This would be too

\footnotetext{
${ }^{29}$ Banks would put a markup on the central bank or prime rate to calculate the borrowing rates paid on deposits. They add the interest rate differential to the borrowing rate in order to arrive at the lending rate. Assisted by monopoly power, banks could set the interest rate differential as a percentage of the central bank or prime rate. Raising that rate under this scenario would mean a higher differential in absolute terms. The total income from bank lending will ultimately depend on its volume.
} 
laborious. The control of money supply would require trading certain value of certificates for each targeted level of monetary base. Selective trading by underlying contracts would not be necessary. We claim that the Sukuk markets for different funding outlets are sufficiently segmented to make government control of their rate of return impossible.

One of the important aspects of the Islamic monetary system is its reliance on the market mechanism. This is an advantage that should not be lost against temptations to interfere in the market. Regulation can enforce the competitiveness of Islamic banking and finance by reducing restrictions on entry and complete avoidance of setting rates of return on either investment accounts or financing provided by banks.

\section{SECTION VI: AGGREGATE LIQUIDITY}

\section{LIQUIDITY DEFINITION}

Monetary economists look at liquidity as a spectrum of assets, with currency on the top, followed by demand deposits, time deposits, government securities, corporate securities and so on. The first layer usually included currency and demand deposits, or $\mathrm{M}_{1}$. The second layer includes saving and time deposits, or quasi money. Both layers are added together of form domestic liquidity or $\mathbf{M}_{2}$. In Islamic finance, currency, demand deposits and investment accounts hold similar liquidity connotations. $\mathrm{M}_{1}$ would be equal to currency plus demand deposits and $\mathrm{M}_{2}$ would be equal to $\mathrm{M}_{1}$ plus investment accounts.

The big difference lies in the rest of government and corporate securities. In Islamic finance, there are no interest-bearing securities issued by economic agents. Sukuk represent titles to combinations of assets, fully 
owned by their holders under real sale. The process of Islamic finance allows banks to create derivative deposits as well as derivative investment accounts. We have argued above for the enforcement of total reserves against demand deposits, while the public and banks to collectively create liquidity in the form of investment deposits.

\section{COST OF LIQUIDITY}

Aggregate liquidity is the responsibility of the monetary authority. It justifies its monopoly over money creation (Friedman and Schwartz, 1963). This assigns the systemic stability role to the monetary authority.

The need for the monetary authority to regulate the financial sector comes from the role played by conventional banks in asset transformation. They have illiquid assets and allegedly liquid liabilities. While economists consider deposits as money, Fama (1980) asserts that bank deposits are not liquid, but they are private contracts with different levels of risk. This must be taken with the fact that investment accounts are not the parallel product to time and saving deposits. They are based on PLS. They can also be based on Musharaka and Wakala. Therefore, the concept of asset transformation takes a different twist in Islamic banking.

The role of the monetary authority, as a regulator and as responsible for aggregate liquidity may be different in the case of Islamic finance. Such responsibility will usually be influenced by whether banks are allowed to produce collectively derivative deposits through the imposition of fractional reserves.

In addition, the "liquidity" created by Islamic banks may have a different effect on the price level due to the fact that Islamic finance, unlike conventional finance, does not 
finance the demand side only. In partnership-in-product and in-profit, Islamic banks finance the supply side, which ultimately influences demand to the extent of payments to factors of production. Sale finance, meanwhile, extends finance to both the demand and supply sides simultaneously. In both cases, the effect of the demand increase on price is attenuated by preceding or parallel effect of an increase in supply. In addition, Islamic banks do not finance risk trade, which could represent an important leakage from the commodity to the financial sector.

Finally, the regulation of Islamic banking based on "supervising liquidity" would require the regulator or the monetary authority to act as the ultimate "fund provider", a role that is parallel to that of the "ultimate lender" in conventional banking. We will take up each one of the three points below.

\section{DERIVATIVE DEPOSITS AND DERIVATIVE INVESTMENT ACCOUNTS IN ISLAMIC BANKING}

When an Islamic bank provides sale finance, it acquires merchandize and assets from suppliers which it provides to customers against future payment. In the instance when the bank acquires merchandize or assets to be grown or manufactured for future delivery against present payment, the bank credits their countervalue to the sellers' accounts. In addition, when it provides Musharaka, PLS or Wakala finance, it places some of the capital provided as a demand deposit into the finance user's account ${ }^{30}$. Therefore, finance users receive cash only when they are not getting their finance in kind.

${ }^{30}$ When a bank provides some or all capital in kind (e. g. land, machinery and equipment), it will make payments to the suppliers of the physical capital. 
Finance users, once received the funds, start spending on their investment activities to purchase factors of production. The cash flows therefrom to the owners of such factors will restart another cycle of flows to banks. In the other instances where Islamic banks provide sale finance, cash is added to the demand deposits of commodity suppliers.

If all such flows or most of them end up with Islamic banks ${ }^{31}$, it provides another cycle of financing to its customers, thereby creating derivative investmentaccounts and derivative demand-deposits with them. Banks will use some of the new balances placed in investment accounts to finance more assets in the Mudaraba pool. New balances in demand deposits will be similarly used. The proportion of the new balances used to create new investment depends on the required reserve ratio applied on such accounts and deposits. This will cause successive rounds of derivative products both as investment accounts and as demand deposits.

\section{THE EFFECTS OF MONEY CREATION BY ISLAMIC BANKS ON PRICES}

From above, we realize that Islamic banks are capable, as a group, of adding to the supply of money through derivative deposits. Banks use balances over and above their liquidity as well as reserve requirements, if any, to invest and add to their assets.

Islamic banks invest through providing finance in the forms of partnership, Wakala, or sale finance. In partnership cases, finance goes to increase the supply of commodities. In sale finance, the bank acquires merchandized and assets from suppliers first and then sell

${ }^{31}$ In a multiple finance system (conventional and Islamic), some funds will flow out of Islamic into conventional banks and vise versa. 
them to customers, stimulating supply and then demand. The time delay between supply and demand stimulation depends on whether the bank acquires merchandize and asset already in inventory or commands their production, as in Istisna'.

In conclusion, the increase in Islamic finance investments due to the increase in money supply in the form of derivative investment-accounts and derivative demanddeposits would have no significant effect on inflation. This is contrary to conventional finance which is mostly directed to demand and can easily be inflationary.

We might add in this respect, that Islamic banks, when properly regulated, should be prohibited from financing risk-trade transactions, e. g., speculation in the stock market or trading in derivatives ${ }^{32}$. This would be an additional measure to prevent money created by Islamic banks to lead to inflation and/or instability.

In contrast, conventional finance provides financial resources to those who trade in risk. Risk trading is done mostly for gambling purposes. It hits the economy from time to time with instability and contagion. Risk trading redistributes wealth haphazardly, and could influence consumption demand directly.

The phenomenon of collective money creation by conventional banks and its effect on the price level, the cost of real balances and wealth redistribution against the public and in favor of banks would all justify regulations in favor of total reserves. However, collective money creation by Islamic banks may have less influence on the price level and the cost of real balances, but would still have the same redistributive effects in favor of banks. The

32 This brings up the question of regulating financial markets under Islamic finance. Obviously, there are several ways of preventing speculation in stocks and trading in derivatives. What concerns us here is that Islamic banks regulations should block any attempts of Islamic banks to finance speculative or risk-trade transactions. 
enforcement of total reserves would still be in order. Meanwhile, more transparency is required in the government use of seigniorage.

\section{THE ULTIMATE LIQUIDITY PROVIDER}

Should the monetary authority claim final responsibility for the aggregate liquidity of the economy, it must stand ready to play the role of the last liquidity provider to banks. However, the role of the lender of the last resort does not seem to apply equally to Islamic banking. The reason is that most monetary authorities regulating and supervising Islamic banks in a mixed financial system do not have the tools to act as the ultimate liquidity provider to Islamic banks.

Monetary authorities perform the function of the ultimate lender through a single conventional means, namely, the discount window; banks requiring extra liquidity can discount some of their government-debt holdings. This would not be acceptable for Islamic banks. The alternative is that the government or monetary authorities issue Islamic investment certificates (e.g., Mudaraba certificates) whose proceeds are invested either directly or through Islamic banks. Banks holding such certificates would sell them in the open market or to the monetary authority to obtain liquidity relief.

\section{CONCLUSIONS}

Islamic banking dependence on mixing and matching between sixteen contracts may appear to bankers, originally trained in conventional banking, as cumbersome and costly. Yet, it has several advantages over conventional finance especially in the areas of information asymmetry, efficiency, stability and debt sustainability. Most of such advantages are reflected as 
external effects in the form of macroeconomic and longrun benefits. Islamic bankers, failing to internalize such benefits, have little incentive to adhere strictly to the Islamic finance paradigm. To the contrary, they have every incentive to mimic conventional finance, with a view to reduce costs and streamline operations. Regulations are therefore required to change such behavior in a way to allow the economy to reap the benefits of Islamic finance.

Regulation that ignores the special characteristics of Islamic finance would hinder the growth of Islamic banks and deprive them from their comparative advantage in handling finance relative to conventional banking. Worse still, such regulation would lead Islamic banks to slip gradually into the practices of conventional finance, ultimately forcing one-sided convergence between Islamic and conventional finance. Islamic finance would then lose its raison d'être and become totally meaningless.

Regulatory and supervisory authorities must seriously consider how differently Islamic banks handle market imperfections in order to design their proper regulation.

Both Islamic and conventional banks benefit from economies of scale in screening customers. However, Islamic banks have a comparative advantage in screening the seekers of sale finance, because of the absence of information asymmetry. Regulation of Islamic banks must verify the existence of proper procedures to offer sale finance and to ascertain the use of financed commodities and their availability as collateral until the finance is fully repaid.

Screening investors seeking finance by Islamic banks requires procedures to verify investment feasibility. Regulation must ascertain that Islamic banks have the capability and resources to perform such function. 
Regulation must insure that banks properly monitor their customers and depositors and investment account holders monitor their banks. Islamic banks face no information asymmetry in sale and Musharaka finance. The monitoring problem is automatically solved, hence. Monitoring partnership finance through PLS and Wakala requires procedures to make it less costly. The paper offers such procedures.

Investment account holders in Islamic banks must monitor their banks because their accounts, unlike demand deposits, are not guaranteed. Regulations must allow for proportionally representing investment account holders on the board of directors of Islamic banks in order to reduce the risk of moral hazard. Regulation must set minimum size and maturity requirements for the representation of account holders.

Both Islamic and conventional banks face maturity mismatch between assets and liabilities. Islamic banks have more tools than conventional banks to close this gap. Regulations must therefore make sure that Islamic banks use such tools to the extent that maturity mismatch becomes negligible.

Conventional banks face greater instability than Islamic banks. Time and saving deposits in conventional banks are guaranteed, both principal and interest. Risk is therefore concentrated in the hands of conventional banks. They tend to shift back this risk to customers at times of crises, by charging higher margins on loans. This behavior includes a higher degree of coordination between banks at times of crises.

Islamic banks, meanwhile, share risk in proportion to their shareholders' equity. Investment account holders face risk in proportion to their account balances. Risk is therefore distributed more uniformly in Islamic finance. 
Islamic banks use the profit stabilization reserve and the investment risk reserve as cushions during times of low profits in order to pay a competitive rate of return on investment accounts.

Regulation must ascertain the buildup of sufficient cushions during good times and their proper use during adversity. They must also make sure that the rate of return on investment accounts is sufficiently higher than the interest rate paid on time and saving deposits, to compensate for the higher risk taken in financing real economic activities rather than providing collateralized loans.

While regulation must provide Islamic banks with procedures to tighten their monitoring of PLS and Wakala investment, the quality of their assets hinges upon product structuring in order to benefit from the risk mitigation advantages of the majority of Islamic finance and investment contracts. Regulation must therefore make sure that banks internal processes include product structuring. Product structures must be tested internally for both business viability and compliance.

Regulation can help Islamic finance deal with the public goods problem. It can set guidelines for the use of Amana finance (PLS and Wakala) in order to facilitate their use in conjunction with Musharaka. In order to prevent the products of ill repute, regulations must clearly define all permissible and non-permissible products and add their definitions in the relevant laws. The regulator must establish a Shari'ah supervisory board in the regulatory agency, while doing away with Shari'ah boards in each Islamic bank

Regulations can prohibit providing subsidies to Islamic banks that face bankruptcy risks. Instead, regulators should offer assistance to customers who face temporary 
insolvency. In addition, heavy penalties should be imposed on delinquent customers.

In Islamic finance, the government would have to compete with the private sector in order to obtain finance for its economic activities from Islamic banks using the Islamic finance and investment contracts. The monetary authority seigniorage is balanced by providing finance to the government through market mechanism on equal basis with the private sector and enforcing transparency and disclosure rules on the seigniorage use by Treasury.

The role of the monetary authority to protect aggregate liquidity depends on whether banks are allowed to produce collectively derivative investment-accounts and demand-deposits through the imposition of fractional reserves. The "liquidity" created by Islamic banks may have a different effect on the price level due to the fact that Islamic finance does not finance the demand side only, but extends its finance to both the demand and supply sides. Finally, the regulation of Islamic banking based on "supervising liquidity" would require the regulator or the monetary authority to properly equip itself to act as the ultimate "liquidity provider"; a role that is parallel but not similar to that of the "ultimate lender" in conventional banking. 


\section{APPENDIX I: DEBT PREDICTABILITY, AN ILLUSTRATION}

\section{UNPREDICTABILITY OF CONVENTIONAL DEBT}

Under conventional finance debt has no predictable maturity. The outstanding value of debt at the $\mathrm{i}^{\text {th }}$ period, or $D_{i}$ is equal to the amount borrowed $B$ minus the amount paid out until the $\mathrm{i}^{\text {th }}$ period, or $\mathrm{P}_{\mathrm{i}}$. In other words:

$D_{i}=B-P_{i}$

Debt service payment at the end of the period (i) is equal to the amount outstanding multiplied by the rate of interest prevailing at $i^{\text {th }}$ period:

$\frac{D_{i}}{(N-i)}\left(1+r_{i}\right)$

Quite often, the borrower could fall into arrears. When this happens, banks add a penalty margin to the current rate of interest and apply it to the whole outstanding balance. This means that the debt service due in the $\mathrm{i}^{\text {th }}$ period is equal to:

$\frac{D_{i}}{(N-i)}\left\{1+\left(r_{i}+p_{i}\right)\right\}$

The total value of debt service for a borrowed amount that is equal to $\mathrm{D}$, is equal to the sum of debt service payments between 1 and N., or

$\sum_{i=1}^{N} \frac{D_{i}}{(N-i)}\left\{1+\left(r_{i}+p_{i}\right)\right\}$

The total amount of debt service would be known only if $\mathrm{N}$, rate of interest prevailing during each period until maturity and the penalty interest margin are known. In most cases, none of the three parameters is known, which makes the value of debt service rather unpredictable. 
Added to this that interest is compounded every period, which can be augmented by the penalty margin, the value of outstanding debt can continue to increase, while the amount of service payment can equal several multiples of the borrowed amount.

\section{PREDICTABILITY OF DEBT UNDER ISLAMIC FINANCE}

In Islamic finance, the amount of finance is the same as the amount to be paid. In other words, the total amount due is equal to the base amount $\left(B_{0}\right.$,cost in Murabaha or spot price in case of deferred payment sale) plus the markup $\left(B_{1}\right)$. The sum of both are divided into equal or unequal installments, to be paid over a certain number of periods, $\mathrm{N}$.

$B=B_{0}+B_{1}=\sum_{i=1}^{N} B_{i}$

All the debt parameters are set from the beginning and the debtor is perfectly certain about their values. Should the debtor run into temporary illiquidity, he will be granted (subject to proving his case) free rescheduling. There will be no penalty rates to apply and consequently no increase in the debt value. 


\section{APPENDIX II: DEFINITIONS OF ISLAMIC FINANCE AND INVESTMENT CONTRACTS}

\section{PARTNERSHIP IN PRODUCT}

Partnership in product started as a way to finance agriculture through joint ventures. Partners share inputs and product according to a pre-agreed formula.

\section{A. MUZARA'A}

A contract between a proprietor and a farmer, where the first provides a piece of arable land and the farmer provides farming labor. Working capital can be provided by either party or both in agreed proportion. Product is shared in an agreed proportion.

\section{B. MUGHARASSA}

A contract between an owner of arable land and a farmer, where the former provides a piece of land and the latter undertakes to plant the same with a certain number of fruit and/or lumber trees of specific types. In return, the farmer earns the title to a share of the land planted with trees.

\section{MUSSAQAH}

A contract between an orchard owner and a farmer, where the first provides an orchard planted with trees producing fruit or lumber and the second provides farming labor. The second party takes care of irrigating, pruning and caring for the trees in return of a share in fruit or lumber. 


\section{PARTNERSHIP IN PROFIT}

Partnership finance is similar to equity finance in the conventional sense. Partners share profit according to a pre-agreed formula. However, sharing loss is strictly according to shareholding.

\section{A. MUSHARAKA}

A contract between two or more partners who provide capital and share management and profit in a joint venture. The objectives of the venture, the proportions of shareholding and profit sharing ratios are set from the beginning. Loss is shared according the capital shares. Shareholders can participate in management either directly or through delegation.
B. MUSHARAKA
MUTANAQISSA
(DIMINISHING MUSHARAKA)

A joint venture of a limited period, where capital shares are extinguished over a prespecified number of years, during which one of or more of the partners buy the shares of others who have agreed to exit at the end.

\section{UNRESTRICTED MUDARABA}

Mudaraba itself is a partnership in profit, between Rabbulmal (the financier) who provides capital, but does not participate in management and the Mudareb (investor) provides investment management. Profit is shared according to pre-agreed proportions. In cases of loss, the financier loses some or all of his capital and the investor loses investment effort.

This contract has been customarily used by Islamic banks to attract deposits (investment accounts). 


\section{RESTRICTED MUDARABA}

In this form of Mudaraba, the activities of the Mudareb (investor) are restricted in the contract. Restrictions can be placed on goods to be traded, sector, countries, in which to invest, etc.

\section{E. DIMINISHING MUDARABA}

The bank supplies the Mudareb with financial resources on Mudaraba basis, with a stipulation that they would be extinguished gradually over a certain number of periods.

\section{SALE FINANCE}

Sale finance is a means through which the financier purchases and possesses goods and services including assets and sells them to a finance user for a price that includes a premium over cost.

\section{A. MURABAHA}

This the most common mode of finance used by Islamic banks. It is a contract in which the finance user signs a promise to purchase certain goods at prespecified costplus price. Based on the promise, the financier acquires and possesses the same goods and then sells them as agreed to the finance user.

\section{B. BAI' BETHAMAN AJEL}

It is a contract through in which the financier sells goods in his or her possession for a negotiated price to the finance user.

\section{ISTISNA'}

It is a contract through which the financier commands the finance user to manufacture certain goods, usually not readily available in the market, and pays the price to the 
manufacturer wholly or partly in advance of, during or after manufacturing. The manufacturer may do the manufacturing himself or through a third party

\section{SALAM}

Salam is a contract through which a financier purchases merchandize that is readily available in the market for future delivery and pays the seller the price spot. One of the advantages of this contract is to facilitate the financing of agricultural crops.

\section{E. IJARAH}

Ijarah is a contract in which the financier sells the usufruct of a property whose title or title to its usufruct he/she holds. Ijarah can also be used with services, like education, travel, etc. The finance user buys the usufruct, pays for it periodically or the services, and pays for them in installments.

\section{F. IJARAH MUNTAHIA BETTAMLEEK}

Ijarah Muntahia Bettamleek is a contract in which the financier sells the usufruct of a fixed asset (e.g., a real estate) and allows the buyer (finance user) to purchase the title to a portion of the asset every year. After an agreed period, the title to the whole asset ends with the finance user.

\section{INVESTMENT AGENCY}

\section{A. UNRESTRICTED WAKALA}

Unrestricted Wakala is a contract through which a fund owner (principal) authorizes an investment expert to invest the funds provided in profitable placements. The agent obtains a commission regardless of the investment results. In addition, the contract may stipulate a profit 
share for the agent, as an incentive, when the profit rate reaches a certain hurdle rate.

\section{B. RESTRICTED WAKALA}

Restricted Wakala may include restrictions on the investment activities exercised by the agent that would limit activities to certain assets, sectors, geographic locations, etc. 


\section{REFERENCES}

1. Adam, Klaus and Roberto M. Billi (2004), "Optimal Monetary Policy under Commitment with a Zero Bound On Nominal Interest Rates," Working Paper No. 377, July. http:// papers.ssrn.com/sol3/Delivery.cfm/SSRN_ID 437141_code170891.pdf?abstractid=437141\&mirid= 1.

2. Al-Jarhi, Mabid (2001), "Islamic Finance: An Efficient and Equitable Option", World Faith Development Dialogue, Berkley Center for religion, Peace and World Affairs, Oct. 10, http:/ / repository.berkleycenter.georgetown.edu/200 11010islamicfinance.pdf

3. Al-Jarhi, Mabid (2005), "The Case for Universal Banking as a Component of Islamic Banking, "Islamic Economic Studies, Vol. 12, 13 (Feb \& Aug.).

4. Al-Jarhi, Mabid (2008), "International Financial Crisis and Islamic Finance," Published in Arabic in three parts series. Part I: http://www.alkhaleej.ae/economics/page/e775729 8-09f8-4397-9a12-202de7d80e3d, 26 Oct., Part II: http://www.alkhaleej.ae/economics/page/af6dd51c -6df1-41c7-bf4d-24c6690f6a54, 29 Oct., Part III: http://www.alkhaleej.ae/economics/page/af62c87b -8ec8-4264-8594-35daa1a8b157 , 30 Oct. A1Khaleej, Economics, Sharjah, UAE, 2008.

5. Al-Jarhi, Mabid (2013), "Gaps in the Theory and Practice of Islamic Economics," JKAU: Islamic Econ., Vol. 26 No. 1, pp: 243-254 (2013 A.D./1434 A.H.)

6. Al-Jarhi, Mabid Ali (1983), "A Monetary and Financial Structure for an Islamic monetary Economy: Institutions, Mechanism and Policy", presented to 
Seminar on Monetary and Fiscal Economics, Islamabad, Jan., 1981, in Z. Ahmad, M. Iqbal and M. Fahim Khan, eds., Money and Banking in Islam, Center for Research in Islamic Economics, Jeddah, and the Institute of Policy Studies, Islamabad.

7. Allen, F. and D. Gale (1988), "Optimal Security Design," Financial Innovation and Risk Sharing. Allen, F., D. Gale, Cambridge and London: MIT Press, pp. 157-97, 1994. Previously published.

8. Andolfatto, David and Ed Nosal (2003), "A Theory of Money and Banking," Working Paper 03-10, October.

9. Andrikopoulos, Panagiotis, Vasileios Kallinterakis, Mario Pedro Leite Ferreira and Thanos Verousis (2015), "Intraday Herding in Cross-Border Exchanges: Evidence from EURONEXT" Journal of. International Financial Markets, Institutions and Money, 23, 55-84. Gelos, R.G., Wei, S.-J., 2005 http://www.efmaefm.org/OEFMAMEETINGS/EFMA \%20ANNUAL\%20MEETINGS/2015-

Amsterdam/papers/EFMA2015_0018_fullpaper.pdf

10. Arevuo, Mikko I (2012), "Market-Based Bank Regulation, Creating incentives that promote responsible banking," Policy Paper, Adam Smith Institute, $\quad$ http://www.adamsmith.org/wpcontent/uploads/ASImarketbasedbankregulation.pd $\underline{\mathrm{f}}$

11. Baliga, Sandeep and Ben Polak (1995), "Banks versus Bonds: A Simple Theory of Comparative Financial Institutions," Cowles Foundation Discussion Paper No. 1100, April.

12. Bhattacharya, S., A. Boot, and A. Thakor (1998), "The Economics of Bank Regulation," Journal of Money, Credit and Banking 30 (4), pp. 745-70, November. 
13. Bikhchandani, Sushil and Sunil Sharma (2001), "Herd Behavior in Financial Markets," IMF Staff Papers, Vol. 47, No. 3.

14. Boortz, Christopher, Dieter Nautz, Simon Jurkatis and Stephanie Kremer (2014), "Information Risk, Market Stress and Institutional Herding in Financial Markets: New Evidence Through the Lens of a Simulated Model," SFB 649 Discussion Paper 2014029.

15. Boot, A. W A and A. Thakor (1993), "SelfInterested Bank Regulation," American Economic Review 83(2), pp. 206-12, May.

16. Campbell, T. and W. A. Kracaw (1980), "Information Production, Market Signaling, and the Theory of Financial Intermediation," Journal of Finance 35, pp. 863-82, September.

17. Chachi, Abdelkader (2005), “Origin and Development of Commercial and Islamic Banking Operations," J. KAU: Islamic Econ., Vol. 18, No. 2, pp. 3-25 (1426 A.H)

18. Chang, H.-J., (1997), "The Economics and Politics of Regulation,' Cambridge Journal of Economics, 21, pp. 703-728.

19. Cipriani, Marco and Antonio Guarino (2012), "Estimating a Structural Model of Herd Behavior in Financial Markets," Federal Reserve Bank of New York, Staff Report No. 561, May.

20. Cipriani, Marco and Antonio Guarino (2010), "Herd Behavior and Contagion in Financial Markets," IIEP-WP-2010-1, Institute for International Economic Policy Working Paper Series, Elliott School of International Affairs, George Washington University.

21. Coenen, Günter and Volker Wieland (2003), "The Zero-Interest-Rate Bound and the Role of the 
Exchange Rate for Monetary Policy in Japan," Working Paper No. 218, European Central Bank, March.

https://www.ecb.europa.eu/pub/pdf/scpwps/ecbw p218.pdf.

22. Diamond, D. W. (1984), "Financial Intermediation and Delegated Monitoring," Review of Economic Studies 51, pp. 393-414.

23. Du, Julan (2003), "Why Banking Regulation? A Theory of Banking Regulation Based on Government Failure,"

November. http://down.cenet.org.cn/upfile/36/200511123472 2196.pdf

24. Economou, F., Gavriilidis, K., Goyalc, A., Kallinterakis, V. (2014), "Herding Dynamics in Exchange Groups: Evidence from Euronext, Journal of International Financial Markets, Institutions and Money ," http://dx.doi.org/10.1016/j.intfin.2014.11.013

25. Edwards, J. and K., Fischer (1994), Banks, Finance and Investment in Germany, Cambridge.

26. Edwards, J. and S. Ogilvie (1995), "Universal Banks and German Industrialization: A Reappraisal", working paper, Cambridge (Feb).

27. El-Gamal, Mahmoud A. (2007), "Mutuality as an antidote to rent-seeking Shariah arbitrage in Islamic finance," (pp. 187-202) Thunderbird International Business Review, Volume 49, Issue 2, first published online: 23 Feb.

28. Eken, Mehmet Hasan, Suleyman Kale, Huseyin Selimler (2013), "The Evolution of Regulations in Banking: a Cycle Based Approach," ACRN Journal of Finance and Risk Perspectives Vol. 2, Issue 2, p. 15 26, Dec. 
29. Elsas, Ralf; Krahnen, Jan Pieter (2003): Universal Banks and Relationships with Firms, CFS Working Paper, No. 2003/20. http://nbnresolving.de/urn:nbn:de:hebis:30-10254

30. Ergun, Deniz Akün (2013), Banking Regulation in Turkey and Russia: An Economic Analysis, PhD European Dissertation in Law and Economics, A Joint European Doctorate Program in Law \& Economics (EDLE) of the Universities of Bologna, Hamburg, Rotterdam and Haifa. https:/ / www.google.com/url?sa $=t \& r c t=j \& q=\& e s r c=s$ \&source $=$ web\&cd $=6 \& \mathrm{cad}=$ rja\&uact $=8 \%$ ved $=0 \mathrm{CEYQFj}$ AFahUKEwj3q9Dey8HIAhWJtBQKHe3_BAU\&url=htt p\%3A\%2F\%2Famsdottorato.unibo.it\%2F5328\%2F\& usg=AFQjCNFb1k1EQYB3RyISAbD9BxQ1aFFqrg\&sig 2=TeQ7SOsFovv30UpClMjPmA\&bvm=bv.104819420, d.d24

31. Fama, E. (1980) "Banking in the Theory of Finance," Journal of Monetary Economics 6(1), pp. 39-57.

32. Ferguson, Charles, Chad Beck and Adam Bolt (2010), Inside Job, documentary.

33. Folhin, C. (1993), "The Role of Financial Intermediation in Industrial Development: The Case of the German Kreditbanken, 1871-1914", Berkeley seminar paper, (Oct).

34. Freixas, Xavier and Anthony M. Santomero (2002), "An Overall Perspective on Banking Regulation," Working Paper No. 02-1, Federal Reserve Bank of Philadelphia, Philadelphia, PA. Also in by A. Boot, S. Bhattacharya, and A. Thakor, eds., Financial Regulation, Oxford University Press, Oxford, England, 2002.

35. Freixas, Xavier and Jean-Charles Rochet (2008), Microeconomics of Banking, Second Edition, The MIT 
Press.

36. Friedman, Milton. 1969. "The optimum quantity of money." In Friedman, M., ed., The Optimum Quantity of Money and Other Essays. p. 1-50. Chicago: Aldine.

37. Fujiki, Hiroshi, Kunio Okina and Shigenori Shiratsuka (2001), "Monetary Policy under Zero Interest Rate: Viewpoints of Central Bank Economists," Monetary and Economic Studies/February.

http: / / citeseerx.ist.psu.edu/viewdoc/download?doi $=10.1 .1 .24 .5481 \& r e p=$ rep $1 \&$ type $=p d f$

38. Gale, D. and M. Hellwig, (1985) "Incentivecompatible Debt Contracts: The One-Period Problem," Review of Economic Studies 52, pp. 647-63.

39. Garner, James M. (2013), "A Critical Perspective on the Principles of Islamic Finance Focusing on Sharia Compliance and Arbitrage," Leeds Journal of Law \& Criminology • Vol. 1 No. 1. http://criminology.leeds.ac.uk/files/2013/09/Islam ic-Finance-Principles_Garner.pdf

40. Giani, Leonardo and Riccardo Vannini (2010), "Toward an Evolutionary Theory of Banking Regulation: The United States and Italy in Comparison" Review of Banking \& Financial Law, Vol. 29, pp. 405-439

41. Goodhart, Ch., Ph. Hartmann, D. Llewellyn, L. Rojas-Suàres and S. Weisbrod (1998), Financial Regulation, Routledge, London/New York.

42. Gorton, G. and G. Pennacchi (1990), "Financial Intermediaries and Liquidity Creation," Journal of Finance 45, pp. 49-71.

43. Gorton, G. and G. Pennacchi (1993), "Security Baskets and Index-Linked Securities," Journal of 
Business 66 (1), pp. 1-27, January.

44. Grossman, S. J. and J. Stiglitz, 1980, "On the Impossibility of Informationally Efficient Markets," American Economic Review, 70, pp. 393-408.

45. Hägg, P.G.T., 1997, 'Theories on the Economics of Regulation: A Survey of the Literature from a European Perspective,' European Journal of Law and Economics, 4, pp. 337-370.

46. Hebbink, G.E. and H.M. Prast (1998), "Regulation and Banking: A Survey," Working Paper No. 565, De Nederlandsche Bank, Amsterdam.

47. Heremans, D. (2000). Regulation of banking and financial markets. In: Encyclopedia of Law and Economics. The regulation of contracts. Cheltenham: Edward Elgar, 950-986.

48. Heremans, D., Pacces, A. (2012). Regulation of banking and financial markets. In: Pacces A., Van den Bergh R. (Eds.), Regulation and economics. Encyclopedia of law and economics, Ch. 13. Cheltenham (UK): Edward Elgar, 558-606.

49. Hilferding, R. (1981), Finance Capital, A Study of the Latest Phase of Capitalist Development, (first published in Berlin, 1910; this edition translated by M. Watnick and S. Gordon, London: RKP, 1981)

50. Kaufman, G.G. (1996), 'Bank Failures, Systemic Risk and Bank Regulation,' Cato Journal, 16.

51. Khan, Feisal, 2010, "How "Islamic" is Islamic Banking," Journal of Economic Behavior and Organization No.76, pp. 805-20.

52. Khan, Mohsin (1986), "Islamic Interest-Free Banking," IMF Staff Papers, Vol. 33.

53. Lee, Yen-Hsien, Ting-Huei Liao and Chih-Ming Hsu (2015), "The Impact of Macroeconomic Factors 
on the Herding Behavior of Investors," Asian Economic and Financial Review, 2015, 5(2):295-304.

54. McCulloch, J Huston (1986), "Bank Regulation and Deposit Insurance," Journal of Business. 59(1), pp. 79-85, January.

55. Metzler, Lloyed A. (1951), "Wealth, Saving and the Rate of Interest," Journal of Political Economy, Vol. 59.

56. Mirakhor, Abbas (1993), "Equilibrium in a noninterest Open Economy," Journal of King Abdulaziz University, Islamic Economics, Vol. 5, pp. 3-23.

57. Ouarda, Moatemri, Abdelfatteh El Bouri and Olivero Bernard (2013), "Herding Behavior under Markets Condition: Empirical Evidence on the European Financial Markets," International Journal of Economics and Financial Issues, Vol. 3, No. 1, pp. $214-228$

58. Ramakrishnan, R. T. S. and A. Thakor, (1983), "Information Reliability and a Theory of Financial Intermediation," Review of Economic Studies 51, pp. 415-32.

59. Reserve Bank of India (2008), "Regulatory and Supervisory Challenges in Banking," Sept. https://rbidocs.rbi.org.in/rdocs/Publications/PDFs 86737.pdf

60. Stigler, G.J. (1971), 'The Theory of Economic Regulation,' Bell Journal of Economics and Management Science, 2, spring, pp. 3-21.

61. Stiglitz, Joseph E. (1994), "The Role of the State in Financial Markets," in Proceedings of World Bank, Annual Conference on Development Economics, Washington, D.C.: World Bank.

62. Swann, D., (1989), 'The Regulatory Scene: An Overview,' in: K. Button and D. Swann, 'The Age of 
Regulatory Reform,' Clarendon Press, Oxford, pp.123.

63. Tampieri, Alessandro and Elena Parilina (2014), "Stability and Cooperative Solution in Stochastic Games," CREA Discussion Paper Series, Center for Research in Economic Analysis, University of Luxembourg.

64. Timothy W. Guinnane (2001), "Delegated Monitors, Large and Small: The Development Of Germany's Banking System, 1800-1914," Economic Growth Center Discussion Paper No. 835, August.

65. Tovar, Jorge, Christian Jaramillo, Carlos Eduardo Hernández (2011), "Risk, concentration and market power in the banking industry: evidence from the Colombian system (1997-2006)," Banks and Bank Systems, Volume 6, Issue 1. 